\title{
THE INTRODUCTION OF ARBITRATION WITHIN THE BRAZILIAN LEGAL CONTEXT
}

Savio R. Sordi

Bachelor in Business Administration with emphasis in Foreign Trade (Unisinos/2004). LL.B. in Law (UniRitter/2013). Lawyer registered in Brazil, subsection of Rio Grande do Sul state.

saviosordi@gmail.com

Tatiana de Almeida F. R. Cardoso Squeff

Ph.D in International Law candidate at UFRGS. LL.M in Public Law (Unisinos/2012), with visiting period at the University of Toronto. Specialist in the English Language (Unilasalle/2008), International Law (UFRGS/2009) and in Contemporary International Relations (UFRGS/2015). Professor of Public International Law at UniRitter (School of Law and International Relations), Unifin-RS (School of Law) and UFRGS (School of Law), Brazil.

tatiafrcardoso@gmail.com

Received: 2015-12-13. Accepted: 2016-02-22.

\begin{abstract}
The present article analyzes the introduction of arbitration as an alternative method of conflict resolution within the Brazilian legal context. In this sense, after a preliminary remark on the origins and concept of arbitration, this text focuses on the construction of the institute of arbitration within Brazilian legal framework. Thus, the aspects regarding the enactment of Law No. 9.307/96 are examined, especially concerning the requisites for the establishment of an effective arbitral convention. Finally, the structure of the law in regard to pre-arbitration facts, such as parties' autonomy and the choice of applicable laws, and the arbitration per se as to the execution of the clause and the aspects concerning the delivery of the award are studied. As a result, the importance of the introduction of such Law it is noticed, as it deeply changed Brazil's legal framework regarding the arbitral convention, making a more palpable and viable method of solving disputes nowadays.
\end{abstract}


Keywords: Arbitration - Law No. 9.307/96 - Arbitration Clause Arbitration Convention

\section{INTRODUCTION}

Brazilian judiciary power is known for its delay regarding the resolution of disputes. Many causes can be listed in order to justify such slowness. For instance, a decade after promulgating its most recent constitution, Brazil had one judge for every 23,090 inhabitants - 6,5 times more than Germany and 4,1 times more than the Unites States for the same period. ${ }^{1}$ Yet, in 2010, that number did not change as the number of suits has been rapidly increasing. ${ }^{2}$ If in 2007 there were about 70,1 million suits pending at the judiciary; in 2013 that number reached the mark of 95,1 million. $^{3}$

In this context, arbitration emerges as a reasonable alternative, especially for the settlement of disputes concerning international trade and other commercial issues. After all, it aims at reaching a fast outcome to a problem, avoiding the need of turning to the judiciary. ${ }^{4}$ Not only that, there are a number of other advantages: variety of places/ institutions accredited, nonalignment, confidentiality, expertise of arbitrators, trustworthiness, equity and the choice of the laws and rules applicable. ${ }^{5}$

Thus, regarding the abovementioned, for a better understanding of the application of arbitration in Brazil, this work attempts to elucidate how the introduction of arbitration happened in the Brazilian legal context, underlining key aspects of Law No. 9.307/96 regarding

1 COSTA, Sílvio Nazareno. Súmula vinculante e reforma do judiciário. Rio de Janeiro: Ed. Forense, 2002, p. 53.

2 CONJUR. Mapa do Judiciário: Brasil tem oito juízes para cada cem mil habitantes. Revista Consultor Jurídico. São Paulo, Feb. 12. 2011. Available at: <www.conjur.com.br/2011-fev-12/ media-brasil-oito-juizes-cada-cem-mil-habitantes>. Accessed in 11 dec. 2015.

3 GONÇALVES, Guilherme. Processos judiciais crescem mais do que a população brasileira. Gazeta do Povo. Pub in Feb. 2, 2009. Available at: <www.gazetadopovo. com.br/vida-publica/processos-judiciais-crescem-mais-do-que-a-populacao-brasileirablq5wwxvk971w6smnz9m1gqj2> Accesed in 11 dec. 2015; BASTOS, Aurélio W.; CARNEVALE, Marcos. O Poder Judiciário e a Justiça em Números. Revista JC. Rio de Janeiro, n. 173, jan.2015. Available at: <www.editorajc.com.br/2015/01/o-poder-judiciario-e-justicaem-numeros/>. Accessed in 11 dec. 2015.

4 Arbitral awards are normally delivered between 6 months to one year after the tribunal has been constituted, whereas in the Brazilian judiciary, it normally takes up to 12 years to reach a final sentence. MAGRO, Maíra; BAETA, Zínia. Guia Valor Econômico de Arbitragem. Rio de Janeiro: ed. Globo, 2004, p. 45; VAZ, Tatiana. Mais Rápido e mais barato. Revista Exame. Pub. Jul. 6, 2006. Available at: <www.exame.abril.com.br/revista-exame/edicoes/871/noticias/ mais-rapido-e-mais-barato-m0083051>. Accessed in $11 \mathrm{dec} .2015$.

5 MUNIZ, Tânia Lobo, Arbitragem no Brasil e a lei 9.307/96. Curitiba: Juruá, 2002, p. 12. 
the choice for arbitration as a way to settle disputes. Therefore, the first part will generally debate the historical and conceptual aspects of arbitration, so that its role as an optional way for settling disputes is established. Subsequently, it will be demonstrated that the development of arbitration culminated in the enactment of the Law No. 9.307, on $23^{\text {rd }}$ of September of 1996.

Consequently, the following topic will explore the structure of arbitration in Brazil, focusing on describing the two existing options for establishing an arbitral convention - the 'Arbitration Clause' and 'Arbitration Agreement'. Finally, the last part of the paper will address the two main phases of arbitration, highlighting specific aspects of pre-arbitration procedures and rules, and the arbitration per se, what includes the formal aspects of the award.

In this sense, it should be noted that this paper does not intend to exhaust the matter; on the contrary, its purpose is to stress how arbitration was inserted in the Brazilian legal context, noting the fundamental importance of Law No. 9.307/96 to the sedimentation of this dispute settlement model within the country. For this reason, a descriptive research will be made by reviewing specific Brazilian literature on arbitration and on the Law No. 9.307/96. To develop this study both historic and monographic procedures will be implemented, so that one may, respectively, understand the basis for the development of arbitration in Brazil, and obtain generalizations through analyzing the Law itself. Thus, as to the techniques, doctrinal and documental research will be applied.

\section{Preliminary Remarks on the origins and Definition of ARBITRATION}

Arbitration dates from the early organized societies, being one of the most ancient judicial alternatives for disputes resolution in the history of $\mathrm{Law}^{6}$. From time to time, arbitration has suffered moments of recognition and underestimation. The first evidence of its use is dated back to 3000 years B.C., more specifically in Babylon, Greece and Rome, as ancient civilization have trusted arbitral tribunals as a viable solution to Private Law disputes. ${ }^{7}$

The development of arbitration gain an improvement as societies, costumes and laws developed, being it a viable institute for conflict settlement and even preventing wars. ${ }^{8}$ After all, the methods

6 MARCO, Carla Fernanda de, Arbitragem internacional no Brasil. São Paulo: RCS., 2005, p.11.

7 PINTO, Luiz Roberto Nogueira, Arbitragem: a alternativa premente para descongestionar o poder judiciário. São Paulo: Arte\&Ciência, 2002, p.19.

8 MUNIZ, op. cit., p.21; PINTO, op. cit. p.19. 
of redeeming differences based on physical force, as self-defense or preemptive behavior, have been gradually replaced by the presence of an arbitrator appointed, especially in the Middle Ages with the ascension of the Catholic Church. ${ }^{9}$

The proliferation of treaties enabling the Pope and its representatives to act as arbitrators brought to the developing societies of the time the legitimacy to resolve matters of sovereignty, successions, family relations, territory, among others ${ }^{10}$. However, with the creation of sovereign states based on the king's will, there was no room for the strengthening of the arbitration, as states Carla Fernanda de Marco:

[t]he absolutism of the governments, which followed the feudalism, has not favored the institute, at least until around the midst of the $18^{\text {th }}$ century. With the French Revolution, the arbitration starts to be considered as an ideal instrument against the Royal Justice System, composed by magistrates still connected to the old regime. ${ }^{I I}$

From that period on, arbitration has suffered moments of recognition and underestimation since " $[\mathrm{t}]$ he creation of the Napoleonic Civil Code, adopted as the basis of almost all European laws, as well as the evolution the Justice administration by the States, has left aside, again, arbitration to a secondary level. It is a must to highlight that also in this period the arbitration tribunals found themselves very procedure oriented". ${ }^{12}$ By the $19^{\text {th }}$ century, on the other hand, arbitration:

\section{[...] gradually, reacquired its relevance as a legal expression of justice making, in issues of litigation for States, individuals and institutions, through the adoption of specific rules in various legal systems, being them private or public, domestic or international, reaching to the conflict resolution of interests through the application of justice in an agile and less procedural matter. ${ }^{13}$}

In addition, the institute of arbitration had also its importance diminished by the continental European Legal System, as known as the

9 MARCO, op.cit., p. 13.

10 GAILLARD, Emmanuel, Aspects philosophiques du droit de l'arbitrage international. Leiden: Martinus Nijhoff, 2008, p. 58.

11 MARCO, op. cit., p. 21.

12 PINTO, op. cit., p. 25.

13 Ibidem, p. 24. 
Civil Law ascension, giving State intervention a most relevant importance on conflict solving. ${ }^{14}$ It was only after 1950 , with "the movement of commerce expansion and the tendency to the opening of markets and internationalization of the economies", that arbitration "reaffirmed itself not only amongst private citizens, but also between States, as an essential institute for the developing international commerce". ${ }^{15}$

In this sense, bearing in mind arbitration is now considered an efficient mechanism for a balanced development of national and international disputes, it is imperative to address the attempt of scholars and jurists to define arbitration, in order to give perspective to the legal operator when dealing with arbitration. The concept and definition of arbitration found in the doctrine introduces some of the most important features of the institute, that is, not only regarding its legal definition, but also by its judicial nature, fundamentally based on its contractual agreement and jurisdictional competence. In that venue, Professor Guido Soares defined:

[a] rbitration is an institute based on the intervention of a third party individual, or individuals, by express request of the litigators, with powers to adjudge a dispute between them, related to facts and rights, in a terminative form. Differently from the national judges, for whom the jurisdiction and competence are defined by an impersonal law, independently of the will of the litigators, the powers of the arbitrator(s) are found determined by the will of such litigators, who, by electing such arbitrators, determine to them, limits, procedures, including deadlines for the exercise of such powers. ${ }^{16}$

From another perspective, Irineu Strenger defined the institute as the "jurisdictional instance, practiced in function of an established contractual regime, to resolve controversies between persons of private and/or public law, with its own procedures, and enforceable before State courts" ${ }^{17}$ Professor Nádia de Araújo has also defined the institute as:

\section{[...] a legal form of controversy resolution, present and future, based on the will of the parties involved, who elect by themselves and directly, or through}

14 MARCO, op. cit, p. 14.

15 MUNIZ, op. cit, p.25-26.

16 SOARES, Guido F. S. A arbitragem e sua conaturalidade com o comércio internacional. In: PUCCI, Adriana Noemi (coord.) Aspectos atuais da arbitragem. Rio de Janeiro: Forense, 2001, p. 121.

17 STRENGER, Irineu. Contratos Internacionais do Comércio. $3^{\mathrm{a}}$ ed. São Paulo: RT, 1998, p. 111. 
the mechanisms by them determined, arbitrators to adjudge the dispute, trusting in them the mission to decide on a mandatory way the litigations by the production of an arbitral award. By the end of the arbitration, ideally, it is expected the award to be executed spontaneously. Its nature in nothing is modified in virtue of it being a domestic or international arbitration. ${ }^{18}$

In this sense, the broad understanding of Brazilian scholars and jurists regarding the institute of arbitration define it as a reliable legal mechanism, based on the manifestation of the litigators will, not bringing the principles and the basis for arbitration on a national or international scenario. However, historically, as previously demonstrated, the institute has presented relative appreciation throughout time, finding its role in the legal setting of the States more strongly in the present, as Modern Statehood has been developed.

Notwithstanding, the Brazilian Legal System has long recognized its role and, analogously, has finally incorporated it by virtue of the Law No. 9.307 of September $23^{\text {rd }}$ of 1996 (hereinafter 'Law No. 9.307/96'). In this venue, it is imperative to address how arbitration came to Brazil and what based the development made by Law No. 9.307/96 much relevant.

\section{THE RECEPTION OF ARBITRATION BY THE BRAZILIAN Legal SySTEM}

Arbitration in Brazil has been recognized since the times of the Portuguese colonization, more precisely it finds its roots based on the Philippine Legal Codes of $1603 .{ }^{19}$ After the Independence, the institute of arbitration in Brazil received various approaches permeated by loopholes and demands suffering a true historic resistance by the legislations that furnished the Brazilian legal system. ${ }^{20}$

The first Brazilian constitution - the Empire Constitution of 1824 - Included arbitration "advancing the theoretical construction that would follow the $20^{\text {th }}$ century to come" ${ }^{21}$ It prescribed that civil disputes, of civil or criminal nature, could be settled by arbitrators nominated by the parties involved, and its award could be carried out

18 ARAUJO, Nádia de. A nova lei de arbitragem brasileira e os princípios uniformes dos contratos comerciais internacionais elaborados pelo UNIDROIT. In: CASELLA, Paulo Borba (coord.) Arbitragem: a nova lei brasileira (9.307/96) e a praxe internacional. São Paulo: LTr, 1997, p.90.

19 PINTO, op. cit, p.25.

20 CARMONA, Carlos Alberto. Arbitragem e processo: um comentário à lei 9.307/96. São Paulo: Atlas, 2009, p. 22.

21 MUNIZ, op. cit, p. 42. 
with no possibility of appeal, if so established. ${ }^{22}$ Moreover, it rapidly disseminated such prescriptions to Brazilian statutes, such as in 1831 establishing its possible use to solve renting services, and in 1850 to mandatorily disentangle conflicts within local trade among partners and maritime trade regarding salvation and damages. ${ }^{23}$

Despite being initially in the vanguard, the Republican Constitution, issued in 1891, left the private arbitration out of its prescription, foreseeing it only in cases that could prevent war, as it was similarly established in the Constitutions of 1934 and 1946. The specific prevision of arbitration as an institute available only for preventing war was not maintained under the 1967 Brazilian Constitution. It, however, included that international disputes could find resort to resolving in arbitration. ${ }^{24}$

The Brazilian Civil Code, according to Carlos Alberto Carmona, mined the arbitration settlement clause at first, and the Code of Civil Procedure of 1939 did not advance as much in terms of arbitral tribunal accreditation. Such approach to the institute has been repeated by the legislators when arbitration found its space in the Code of Civil Procedure of $1973 .{ }^{25}$ Even the acclaimed jurist Pontes de Miranda, one of the greatest in history, understood arbitration as "primitive, regressive", and an attempt to circumvent State power, being it, according to him, "an efficient weapon to a late capitalism". ${ }^{26}$

It has not taken long, according to Carmona, for all the "negative noise" to settle down in virtue of reality: arbitration "has not reveal itself as a savage and abused form of resolving disputes" and " the alternative means for dispute resolution flourish in Brazil, Latin America and throughout the planet". ${ }^{27}$

It is imperative to note that even though arbitration has not been well received by past Brazilian legislation, it has yet been used as conflict resolution in many circumstances, such as territorial disputes between Argentina and Brazil in 1900 (favorable to Brazil), the United States shipwreck patrimonial dispute against Brazil of 1879 (favorable to USA) and the dispute against Great Britain, regarding the arrest of English officers in 1863 (favorable to Brazil) to quote a few. Not to mention famous historical figures such as Barão do Rio Branco,

22 PINTO op. cit, p.27.

23 MARTINS, Pedro A. Batista. Arbitragem Através dos Tempos. Obstáculos e Preconceitos à sua Implementação no Brasil. In: GARCEZ, e José Maria Rossini. A arbitragem na Era da Globalização. Rio de Janeiro: Forense, 2003, p. 43.

24 MUNIZ, op. cit, p. 42.

25 CARMONA, op. cit, p. 26.

26 PONTES DE MIRANDA, Francisco C., Comentários ao Código Civil. Tomo XV. Rio de Janeiro: Forense, 1977, p. 344.

27 CARMONA, op. cit, p. 26-27. 
Barão de Arinos e Visconde de Itajubá, all involved in arbitrations and enthusiasts of the institute..$^{28}$

It was only with the establishment of the Law No. 9.307/96 that arbitration took a definite step for permanent placing in the Brazilian Legal System. The bill that resulted in such contemporary law has been instituted under the supervision of highly recognized experts on the matter: Selma M. Ferreira Lemes, an expert on international law, Pedro A. Batista Martins, an attorney in Rio de Janeiro and Carlos Alberto Carmona, professor at São Paulo Law School. ${ }^{29}$ And through the hands of Senator Marco Maciel, the bill received the necessary attention of Brazilian legislators, starting its processes of maturation in 1992.

Although arbitration had been incorporated throughout recent legislation, gaining more and more space, it had always a set back position that actually did not make the full use of the institute available. It is the case of Law No. 9.099 of September $26^{\text {th }}$ of 1995 , regarding the Small Claims Court Regulation of civil and criminal nature, which recognized the possibility of choosing an arbitrator for the dispute an year before the advent of Law No. 9.307/96; however, the resulting decision had to expressly be confirmed by a State Legal Authority. ${ }^{30}$

According to Carmona, in his analysis after ten years the Law entered into force and six after he wrote the first edition of Arbitragem e Processo, um Comentário à Lei $N^{\circ}$. 9.307/96 - considered an outstanding doctrine on the matter in Brazil - arbitration is now a case of great success. In his words:

[t]he undeniable success of arbitration in Brazil takes me, though, to present the third edition of Comentários which I submitted to the legal community in 1998. Much have changed since then: what was pure theory became practice and everyday routine; what was an impression became a fact; what was speculation entered in the world of facts. [...] I considered myself fully satisfied, since everything that was foreseen has actually happened accordingly to what was expected: fear has been overcome (normal reaction to the unknown), the arbitration has been rediscovered. ${ }^{31}$

28 PINTO, op. cit, p.26-27.

29 DELGADO, José Augusto. A arbitragem no Brasil: evolução histórica e conceitual. Revista Jurídica Consulex. Brasília, v.1, n.11, pp.5-9, nov. 1997, p. 7 (footnote n. 14).

30 PINTO op. cit, p. 29.

31 CARMONA, op. cit, p. 27. 
In this venue, it is possible to state that the "expression of arbitration' was complete with the adoption of Law No. 9.703/96, as it meant to totally replace the outdated arbitral system accepted in Brazil until $1996 .{ }^{32}$ It came to overcame all major obstacles that have turned the previous regulations ineffective, perpetrating the century-long practice within Brazil and modernizing its Legal System, as to align it with the most developed countries methods' of solving disputes - what is even seen as a requirement for the expansion of Brazil's insertion in the international economic order. After all, as Rodrigo Bernardes Braga highlights about the usage of arbitration by/in Brazil: "[i]t is natural that the institute, as a general system of dispute resolution, [should be] treated in a harmoniously way by the other countries aiming to avoid setbacks and useless efforts".33

The new structure set out by Law No. 9.703/96, thus, enabled the arbitral jurisdiction, strengthening the application of the arbitration clause, which by itself, became capable of refraining State judge competence. It also regulated the enforceability of the arbitral award, which have found fierce resistance, suffering challenges of all sorts, such allegations of being unconstitutional, or loopholes on the civil legislation, and, now, has the same force as a State judge ruling.

As a result, it is clear that not only it guaranteed the full application of the institute, but also facilitated the execution of international arbitral awards in Brazil - another good practice brought by it since arbitration can be seen a clear movement toward the relaxation of the case overload that the Brazilian Judiciary Power is currently subjected to. Thus, there is a need to closely analyze the new structure set out by Law No. 9.703/96 so that one may understand the basic issues regarding arbitration in Brazil, what is subsequently exposed.

\section{The STRUCTURE OF ARBITRATION IN ACCORDANCE TO LAW No. 9.307/96}

Law No. 9.307/96 is divided in seven chapters and 44 articles, and is not part of the Code of Civil Procedure of Brazil. In accordance to Carlos Alberto Carmona it would be preferable that the law had followed the standards of incorporation in the legal system present in countries like Italy and France, which had inserted the institute within their Civil Procedure Codes, avoiding the displacement of procedural principals in accessory laws. ${ }^{34}$

On the other hand, the fact the Law No. 9.307/96 does not only regulates procedural rules, the choice of the legislator in setting the

32 PINTO, op. cit, p.29.

33 BRAGA, Rodrigo Bernardes. Teoria e Prática da Arbitragem. Belo Horizonte: Del Rey, 2009, p. 56.

34 CARMONA, op. cit, p.14. 
rules apart from the Code of Civil Procedure, left room for a better and broader approach in order to overcome previous obstacles. In those measures adopted it is included the revocation of conflicting articles from the Civil Code and the previous arbitration regulations, which have held back the full application of the institute in the Brazilian context.

Notwithstanding, it is imperative to understand that national law will always have an impact in the exercise of arbitration. It is to be noted that, under sovereignty, it is the State's prerogative to enforce the law, and, as a consequence, it is the same State that shall recognize the international arbitral award and provide a legal environment to execute such award, if not spontaneously fulfilled.

Not only in such cases where the foreign award needs to be executed in Brazil, the 'Arbitration Convention' also has to be recognized (if no restraints are found ${ }^{35}$ ) by the judicial system whenever prearranged, each and every time a party tries to argue its non-applicability so as to use the judiciary system of a State. After all, previous legislations which have kept arbitration in Brazil much of problem than a respectful institute to solve disputes, despite of recognizing arbitration from time to time, regarding its effects, they were repeatedly overruled by the State-judges bringing the competence back to the jurisdiction of the State.

Moreover, the judiciary may be currently used as well in order to reinforce the choice for arbitration made by the parties. That is to say, if any of the parties expresses resistance to follow through with the arbitration agreement, the new law foresees a fast and efficient way to enforce it, as it now has a "mandatory and binding character, obliging the parties to institute the arbitration" ${ }^{36}$, which may be executed by the State to establish the arbitration agreement at once.

Thus, the new legislation corrected the legal flaws of the previous ones by establishing the 'Arbitral Convention', which consists of an 'Arbitration Clause' or an 'Arbitration Agreement'. In other words, in the current Brazilian Legal System, very much alike the French Legal System, the arbitration convention is bipartite, understanding the institute as divided in an 'Agreement' and in a 'Clause'. ${ }^{37}$

35 Law No. 9.307/96 precludes certain issues to be subject of arbitration. The issues that are of exclusive competence of the State are questions regarding State matters, personal family rights (especially involving minors), and any other issues that are not strictly of patrimonial matter. In Carlos Alberto Carmona words: "[i]n general, are not within the available right questions relating to family law - and in particular the status of persons (membership, paternal power, marriage, food) - those relating to the right of succession, those that aim at things out of the trade, the natural obligations, relating to criminal law, among many others, since these matters are all outside the boundaries that can act freedom of choice of contenders" (CARMONA, op. cit, p. 56).

36 MUNIZ, op. cit, p.88.

37 GUERRERO, Luis Fernando, Convenção de arbitragem e processo arbitral. São Paulo: 
An 'Arbitral Agreement' may be understood as the one where the parties "obliged themselves to utilize the [arbitration] means for conflict resolution" in a formal contract. ${ }^{38}$ The Law in question defines 'Arbitral Agreement' as it follows:

Article 9. The arbitral agreement is a convention through which the parties submit its quarrels to the arbitration of one or more people, being it judicial or extrajudicial. $\S 1^{\circ}$ The judicial arbitral agreement shall be concluded by term in the records before the Court or Tribunal where the suit is being processed. $\S 2^{\circ}$ The extrajudicial arbitral agreement shall be celebrated in private by writing, signed by two witnesses, or by public act. ${ }^{39}$

However, it should be noted that the agreement may be signed either in an ongoing quarre ${ }^{40}$ or previously to a dispute. ${ }^{41}$ On this matter Luís Fernando Guerreiro clearly explains that:

[t] he arbitration agreement is the way to institute the arbitration traditionally utilized when the dispute already exists, which is, existing the dispute between the parties they can define the arbitration as a form of solution. Nothing prevents, however, that before the dispute arises, but during the legal relationship between the parties, they sign an arbitration agreement foreseeing issues that shall be dealt through the means of arbitration, even though such situation is not common. ${ }^{42}$

On the other hand, the 'Arbitration Clause' is a mere clause of a contract, which establishes the choice of dispute resolution by

Atlas, 2009, p. 6.

38 MUNIZ, op. cit, p. 85.

39 BRASIL. Lei da Arbitragem - Lei Federal 9.307. Brasília: Senado Federal, 1996. Art. 9.

40 For parties reviewing contracts already in force, this possibility can serve to better commercial relations. According to Carlos Alberto Carmona, in case of late inclusion of the arbitration clause, such clause "shall be agreed through the exchange of correspondence, telegrams, telex, or even facsimiles that report to a legal business, foreseen the solution to eventual and future disputes through arbitration"(CARMONA, op. cit, p. 17).

41 BRAGA, op. cit, p. 49.

42 GUERRERO, op. cit, p. 7-8. 
the parties in the case of a misunderstanding. ${ }^{43}$ In other words, the 'Arbitration Clause' is the agreement regarding future disputes, where the parties agree to undertake any disputes arisen from the contract to arbitration, and they do so by inserting a clause to the contract. Luís Fernando Guerreiro elucidates this issue:

[...] the arbitration clause is typically inserted in
legal agreements between parties and, because
of that, it is characterized as the convention of
arbitration prior to the dispute. It is foreseen at the
moment that the parties sign the contract which
its enforcement is expected to happen without any
setbacks, being latent the clause until the occurrence
of a dispute to be solved. ${ }^{44}$

It should be noted that the Brazilian legal system had never formally recognized nor inserted the 'Arbitration Clause' until the advent of Law No. 9.307/96, which brought the following arrangement:

Article 4. The arbitration clause is a convention through which the parties in a contract agree to submit to arbitration the disputes that may surface, related to such contract. $\S 1^{\circ}$ The arbitration clause must be stipulated in writing, being it included within the contract or in an separate document which refer to it. $\S 2^{\circ}$ In the adhesion contracts, the arbitration clause shall only have effect if the party takes the initiative to institute arbitration or if the party agrees, expressly, to its institution, provided that is in writing in the attached document or in bold, with the signature or acknowledgment especially to this clause. ${ }^{45}$

As a consequence, currently, either if the arbitration is foreseen in a "mere" clause within a contract or if a full arbitral settlement is properly established, the State's participation in the private matter limits itself to the execution of the 'Arbitral Convention' or to compel the resistant party to the arbitral procedure whenever an 'Arbitration Agreement' has been established.

43 It should be noted that both of them "includes the choice of norms that shall govern the arbitral tribunal, the definition of the conflict and the choice of arbitrators" (MUNIZ, op. cit, p. 85).

44 GUERRERO, op. cit, p. 6-7.

45 BRASIL. Lei da Arbitragem - Lei Federal 9.307. Brasília: Senado Federal, 1996. Art. 4. 
Considering that both options are prescribed by Law No. 9.307/96, it is deemed important to draw the similitudes and differences between the 'Arbitration Clause' and the 'Arbitration Agreement', in order to make it easier for one to consider while drafting or analyzing the arbitral convention. Hence, it should be stated both clauses are similar as they (a) need to be in writing; (b) attain to general rules of contract validity; (c) are independent from the contract where they are inserted in; (d) enable the person of the arbitrator the power to adjudge regarding the validity and enforceability of itself and the contract where they are inserted or are part of; and (e) refrain the State intervention forcing the parties to resolve the matters through arbitration. ${ }^{46}$

On the other hand, the differences between them encompass relevant facts. The first, would be the mandatory formal aspect in the case of the 'Arbitration Agreement', which is the indispensability of nominating, in writing, the arbitrators, parties and dispute matters - as Article 10 prescribes - and the requirement of two signing witnesses; whether on regard of the 'Arbitration Clause', no extraordinary requisites are necessary, being sufficient its establishment in one clause within a contract, in a separate document, in the duration of the contract or after its term.

Another great difference, according to Tânia Lobo Muniz, is the time aspect, as she explains:
[w] hilst the 'Arbitration Clause' is conditional, generic and a future one, creating an obligational chain, it is established by the will of the parties by signing the agreement. Such agreement aims to resolve an undefined number of disputes. The 'Arbitration Agreement' is definite, specific and a present one, aiming to resolve disputes already existent and defined, through the institution of the arbitral court. ${ }^{47}$

In that sense it is possible to infer that even though differences are evident regarding the clause and the agreement, Law No. 9307/96 properly kept the jurisdiction of the State excluded, "proportionating more legal certainty, and consequently more development for the utilization of the arbitral via in Brazil". ${ }^{48}$ Noting the existence of both possibilities and its punctual changes to the country's dispute solution mechanism, it is also necessary to address the phases and requisites that arbitration in Brazil encompasses. 


\section{THE PHASES OF ARBITRATION IN BRAZIL}

In order to set out significant parameters for perfectly adopting the institute, the arbitral procedure in Brazil consists in two phases: the first known as the contractual phase, i.e., the establishment of an 'Arbitration Agreement' or the drafting of an 'Arbitration Clause'; and the second called the execution phase, where the arbitral procedure per se takes place. ${ }^{49}$ Brazilian legislation foresee these two stages of arbitration in Article 3 of the Law No. 9307/96, establishing that the parties may submit its disputes to arbitration (initiating the second step) whenever they have convened to do so through either of those clauses. ${ }^{50}$

The first requisite that must be present in the contractual phase is the willingness of the parties to freely agree to the clause or to the agreement. In other words, Law No. 9.307/96 has established that arbitration is once contracted if agreed by the parties. However, in order for the parties to contract a legal 'Arbitral Agreement' or agree to an 'Arbitration Clause', it is a must that each contracting individual is considered capable of exercising its civil rights in accordance to the laws where they permanently live, due to the lex domicilii rule. The capacity of a person within Brazil falls under the laws and regulations of one's residency, a known technique of Private International Law that may be seen as the most appropriate one regarding capacity issues. ${ }^{51}$

Not only that, Brazilian law expressly authorizes the parties to freely establish the clauses that will govern such choice in Article 2 of Law No. 9.307/96. ${ }^{52}$ That is to say that the parties may choose not only on what grounds the arbitrators will be chosen, but also the law that the arbitrator shall apply in case of a dispute. ${ }^{53}$ In this venue, it channels special importance to the parties' autonomy, being the observance of the 'Autonomy at Will Principle' imperative for this phase. According to Irineu Strenger, such principle corresponds to

\section{[...] the option given to individuals to exercise their will, given the choice and determination of applicable law and certain legal relations in international relations, deriving from the confidence that the international community gives}

49 Ibidem, p.99.

50 BRASIL. Lei da Arbitragem - Lei Federal 9.307. Brasília: Senado Federal, 1996. Art. 3.

51 Cf. UNICITRAL. Lei Modelo da UNCITRAL sobre Arbitragem Comercial Internacional. 1985. Art. 28(2); BRASIL. Lei de Introdução as Normas do Direito Brasileiro - Decreto 4.657. Brasília: Senado Federal, 1942. Art. 7; MERCOSUL. Protocolo de Buenos Aires sobre Arbitragem Comercial Internacional. 1998. Art. 7(1).

52 BRASIL. Lei da Arbitragem - Lei Federal 9.307. Brasília: Senado Federal, 1996.. Art. 2(§1).

53 MARCO, op. cit, p.27. 
to the individual in the interest of society, and being exercised within the state boundaries. ${ }^{54}$

Such autonomy given is broad and intends to repel doubt regarding the choices. As Rodrigo Bernardes Braga explains, "the Brazilian arbitration law allows the use of national rules, non-national rules, general principals of law, uses and customs, and international rules of commerce for resolving the dispute". ${ }^{55}$ Therefore, the attorney points out that such broadening approach could bring the parties to opt, even, for a set of customary rules arising from international trade over the years (lex mercatoria ${ }^{56}$ ), a practice whose "origin goes back in the time of the great overseas conquests, based on the commerce polices of goods exchange performed between the civilizations". ${ }^{57}$

Actually, this is one of the few possibilities for one to choose the law that will govern a dispute in Brazil, as in regular contracts not foreseeing arbitration it is not deemed possible ${ }^{58}$ and the other possibility is only valid within commercial arbitrations among parties belonging to Mercosur. ${ }^{59,60}$ The only limitation it may encounter is Brazil's Public Order, National Sovereignty or Local Customs as stipulated by the 'Introductory Rules of Brazilian Law Code' and Law No. 9.307/96, which shall be followed by the Brazilian judiciary whenever intending

54 STRENGER, op. cit, p. 114.

55 BRAGA, op. cit, p. 17.

56 Such practice has started whilst the great commerce fairs were booming in England. It indicated that the close community of businesspeople had already prepared an arbitration tribunal within the fairs to solve eventual disputes among the commerce owners, stating a clear sign that such disputes "could not be solved under the light of the English laws". As a conclusion, in virtue of such practice, the domestic law gave space to the application of other rules, external norms, exception granted to the international commerce within national borders (BRAGA, op. cit, p. 19).

57 Ibidem, p. 17.

58 Art. 9 of the Introductory Norms of Brazilian Law foresees that the law applicable to a dispute will depend on the locus regit actum technique, that is, to the place where the contract has been signed - except in labor-related contracts (BRASIL. Lei de Introdução as Normas do Direito Brasileiro - Decreto 4.657. Brasília: Senado Federal, 1942. Art. 9).

59 Art. 10 of Buenos Aires Protocol (internalized by Brazil under Decree No. 4.719/03, thus, being it legally applicable throughout Brazilian territory) allows the parties to "chose the applicable law to their disputes based on private international law and its principles, or in the commercial arbitration law' (MERCOSUL. Protocolo de Buenos Aires sobre Arbitragem Comercial Internacional. 1998. Art. 10).

60 Note that the Interamerican Convention of Applicable Law to International Contracts, erected in 1994 under the auspices of the Organization of American States - OAS, and which foresees the 'Autonomy at Will' principle in Art. 7, although signed by Brazil, is not yet into force within its territory as it was not yet promulgated by the Brazilian president (OEA. Convenção Interamericana sobre Direito Aplicável aos Contratos Internacionais. 1994. Art. 7). 
to recognize an arbitral award ${ }^{61}$, i.e., when attributing efficacy to it. $^{62}$ After all, "in case of any qualification conflict between an imperative system and an elective system on a certain legal matter, the issue would be outside the frame of autonomy, as it only becomes effective if it could be [locally] enforced". ${ }^{63}$

Thus, this restriction regards "the impossibility of affronting state rules, perfectly emanated from the Legislative Power and that prescribe for the maintenance of the Democratic State of Law". ${ }^{44}$ Nonetheless, if the foreign arbitral award is not intended to be enforced in Brazil, there is no need for observing such rules, as the validity of the chosen law rests under the auspices of the abovementioned principle - and not in the statutory norms and customary rules of a given legal system.

Another issue that is stipulated in this phase is the choice of the arbitrators by the parties. It should be noted that in the arbitral procedure, the arbitrator is the most important figure since it is a third party to the dispute, neutral, apart from the conflict, to whom it is trusted the solution for the problem. ${ }^{65}$ In consonance with the words of Article 13 of the Law No. 9.307/96 the arbitrator can be "any person capable and which has the trust of the parties"66, and are appointed by the ones in disagreement. In this venue, Cristina Schwansee Romano summarizes:

61 It should be stated that arbitral awards are only forcible in Brazil with the Brazilian judiciary authorization, which shall be granted by the 'Superior Tribunal de Justiça' (the Brazilian Superior Court of Justice), in accordance to the the Constitutional Amendment no. 45 of 2004, which removed the attribution to recognize arbitral awards from the Federal Supreme Court. Besides, it should be stressed that because of Law No. 9.307/96, the procedure to confirm the awards has changed. Before there was a 'dual procedure' according to which the award should be sanctioned by the judiciary power of its home country (i.e. country that delivered the arbitral award), and then by the Brazilian courts, causing enormous trouble to the application of arbitration in Brazil, as some nations did not see the confirmation by their judiciary power needed what consequently led to the non-recognition of the foreign awards by Brazilian courts. Nowadays, in accordance to Law No. 9.307/96, there is no need for the award to be previously recognized by the country where the arbitration procedure has taken place (MARCO, op. cit, p. 28; SOARES, Guido Fernando Silva. O Supremo Tribunal Federal e as arbitragens comerciais internacionais: de lege ferenda. Revista dos Tribunais. São Paulo, a.78., v. 642, pp. 38-71, abr. 1989, p. 65; BRASIL. Lei da Arbitragem - Lei Federal 9.307. Brasília: Senado Federal, 1996. Arts. 34 through 37).

62 BRASIL. Lei de Introdução as Normas do Direito Brasileiro - Decreto 4.657. Brasília: Senado Federal, 1942. Art. 17; BRASIL. Lei da Arbitragem - Lei Federal 9.307. Brasília: Senado Federal, 1996. Art. 2(\$1) and 39(I)(II).

63 STRENGER, op. cit, p. 114.

64 AZEVEDO, Pedro Pontes. A Lex Mercatória e a sua aplicação no ordenamento jurídico brasileiro. Revista Prima Facie. João Pessoa, a. 5, n. 9, pp. 93-105, jul./dez. 2006, p. 100.

65 PINTO, op. cit, p. 92.

66 BRASIL. Lei da Arbitragem - Lei Federal 9.307. Brasília: Senado Federal, 1996. Art. 13. 
[a]n arbitrator is any capable person who has the trust of both parties can be an arbitrator. The choice of the arbitrator is made by the parties, or by the procedure stipulated by them. The selection of arbitrators must result in an odd number. If the parties appoint an even number of arbitrators, the selected arbitrators will appoint one more arbitrator. ${ }^{67}$

Besides such important issues, there are other imperative requisites that are specific to each type of the arbitration convention. Regarding the 'Arbitration Clause', it is essential that it stipulated in writing, being it wither inserted within the contract or in a different document related to the main agreement. ${ }^{68}$ In the case of an 'Arbitration Agreement', there are other indispensable elements that must be present in order for it to be considered valid.

In accordance to Article 10 of the Law No. 9.307/96, as prescribed by Cristina Schwansee Romano, the requisites include:

(1) the name, profession, marital status and domicile of the parties; (2) the name, profession and domicile of the arbitrator(s), as the case may be, the particulars of the entity to which the parties have delegated the appointment of the arbitrators; (3) the matter referred to arbitration; (4) the place where the arbitration award will be issued. [Not only that, the] arbitration agreement may also include: (1) the place where arbitration is to be conducted; (2) any authorization for the arbitrator(s) to decide on equity; (3) the deadline for submission of an arbitration award; (4) the citation of the laws or statutes applicable to the arbitration; (5) the declaration of liability for payment of arbitration fees and charges; and (6) the setting of arbitration fees. ${ }^{69}$

On the requisite regarding the authorization for the arbitrator to decide on equity, that is, the possibility of the arbitrators to judge based on legal principles that supplement strict rules or norms of law, it should be noted that it does not allow arbitrators to abandon

67 ROMANO, Cristina Schwansee. The 1996 Brazilian Commercial Arbitration Law. Annual Survey of International \& Comparative Law. San Francisco, v. 5, n.1, pp. 27-47, 1999, p. 36. 68 BRASIL. Lei da Arbitragem - Lei Federal 9.307. Brasília: Senado Federal, 1996. Art. 4(§1). 69 ROMANO, op. cit, 38. 
the observance of legal norms of law. ${ }^{70}$ Furthermore, on the matter of deadline fixation, Carmona brings an important guideline stating that it is "convenient" that the parties to establish a deadline for the issuing of the arbitral award. If the parties do not fixate the deadline, Article 23 of Law No. 9.307/96 prescribes that such deadline is to be no longer than six months. ${ }^{71}$

Regarding the setting of fees, it is understood that an arbitrator is to be rewarded monetarily for its services, and since it is optional to foresee this requisite, in case of non-definition of such fees the arbitrator could seek for payment through the State's competent legal court. Nonetheless once such fees are properly established in the arbitration agreement, they are to be considered an extrajudicial executable title. ${ }^{72}$

After such agreement or clause is set, the parties may force its application whenever discrepancies to what has been established in the contract arise. In such scenario, instead of seeking justice through the judiciary of the state, one may invoke arbitration, and call upon the other party to execute either the agreement or the clause, initiating the arbitration per se - the second stage of the arbitration.

The arbitration is deemed initiated by the acceptance of the appointed arbitrator(s) of the proceedings. Then, the arbitrator(s) will analyze all the information and requisites prescribed in the clause or in the agreement in order to verify any inconsistency so that the missing provisions may be set out in an additional term, agreed upon all parties, in accordance to Law No. 9.307/96, Article 19 and its paragraphs. ${ }^{73}$

The procedure just ends when the arbitrator(s) release an arbitral award, which shall be express and in writing ${ }^{74}$, containing a report summarizing the dispute, the legal reasoning explaining the outcome, and the decision itself along with its compliance methods. ${ }^{75}$ It will be issued either on a specific date set by the parties or in six months from the date the arbitration per se has initiated - being it extendable by the arbitrator(s) will. ${ }^{76}$ Besides, whenever the arbitration consists of more than just one arbitrator and there are divergent positions, the opposing arbitrators may also deliver their own separate awards within such period, even though the decision of the arbitral tribunal president is the

70 CARMONA, op. cit, p.20.

71 Ibidem, p. 21

72 Ibidem, p. 21-22.

73 BRASIL. Lei da Arbitragem - Lei Federal 9.307. Brasília: Senado Federal, 1996. Art. $19(\S 1)(\S 2)$.

74 BRASIL. Lei da Arbitragem - Lei Federal 9.307. Brasília: Senado Federal, 1996. Art. 24. 75 BRASIL. Lei da Arbitragem - Lei Federal 9.307. Brasília: Senado Federal, 1996. Art. 26. 76 BRASIL. Lei da Arbitragem - Lei Federal 9.307. Brasília: Senado Federal, 1996. Art. 23(§1)(§2). 
one prevailing if there is no majority award. ${ }^{77}$

Such award is, thus, final. However, there is a possibility to appeal the decision within 05 (five) days of the notification of the award, if no other date has been stipulated by the parties. ${ }^{78}$ The appeal prescribed by Law No. 9.307/96 allows the interested party to request the arbitrator or the tribunal to correct any material inconsistency of the award, or even to clarify any obscurity, doubt, contradiction or eventual omission of the award. ${ }^{79}$ Such appeal should normally be delivered in no more than 10 days. ${ }^{80}$

After that, the arbitral award becomes an enforceable executive title. ${ }^{81}$ As expressed above, under the Brazilian Legal System, the award delivered by foreign arbitral tribunals are deemed valid, only lacking efficacy in the Brazilian territory, which shall be granted by the judiciary. Yet, regarding the arbitral awards produced in national territory, there is no need for approvals, confirmations or sanctions in view of the Law No. 9.307/96, as the awards nationally delivered currently have the same status as sentences, rulings or court orders delivered by the Brazilian Judiciary Power. ${ }^{82}$

\section{Concluding Remarks}

It is reasonable to conclude that much have changed in the arbitration scenario in Brazil since the enactment of Law No. 9.307/96. Such movement acts in consonance with the international tendency of law renovation regarding the current stage arbitration worldwide. Now it is safe to say that arbitration became a reliable tool for the development of legal affairs in national territory.

The fact that important scholars and jurists have dedicated their efforts to study the development of arbitration worldwide reflected in abundant material for the formulation of the bill that based the issuing of the new law. After all, the retrospect of arbitration under the Brazilian history, and especially the multiple flaws the previous law presented, had arbitration held back within Brazil. And due to the profound studies made capturing the loopholes of the previous laws and preparing the legislators with a solid base for the change, it became evident that a series of flaws present in the previous legislation was left behind with

77 BRASIL. Lei da Arbitragem - Lei Federal 9.307. Brasília: Senado Federal, 1996. Art. $24(\S 1)(\S 2)$.

78 BRASIL. Lei da Arbitragem - Lei Federal 9.307. Brasília: Senado Federal, 1996. Art. 30.

79 Ibidem.

80 Ibidem.

81 BRASIL. Novo Código de Processo Civil - Lei Federal 13.105. Brasília: Senado Federal, 2015. Art. 515(VII).

82 CARMONA, op. cit, p. 346. 
the new legislation in force.

Key aspects such of Law No. 9.307/96 were truly innovative within the national legal framework. First, the differentiation of an 'Arbitration Clause' and 'Arbitration Agreement' was very important for the consolidation of arbitral conventions in Brazil, leaving both, clause and agreement, independent from each other, but individually enforceable. That is because they both represent the main aspect of arbitration, which is the acceptance of the party to this alternative method of dispute resolution - the "consummation" of arbitration. On the same token, regarding the matter of the arbitration clause, the minimum requirements that a party should observe in order to avoid state intervention, are a guarantee that arbitration, whenever chosen as the method for conflict resolution by the parties, will take place.

Moreover, the fact that the parties under Law No. 9.307/96 enjoy the autonomy of will to choose the applicable substantive law that they understand fit to their reality is another positive aspect introduced, as this was the first step Brazil ever took towards the acceptance of the 'Autonomy at Will Principle'. Even though Brazil has not internalized yet the OAS Interamerican Convention of Applicable Law to International Contracts, it would not be much forceful to say the new law encouraged the acceptance of Buenos Aires Protocol signed under the auspices of Mercosur, which predicts the same principle.

Furthermore, by establishing the main aspects of the award, the Brazilian law enacted in 1996 made it clear that its intention was to make arbitration a reliable way of solving disputes in Brazil. By holding such aspects, the (national) arbitral award becomes a valid executive title, which is to be enforced between the parties, based on the territorial approach. And on the matter of foreign ones, Law No. 9.307/96 also positively innovated as it does not prescribe for the a dual procedure system anymore, just requiring the alien award to be confirmed by the competent Brazilian court, which, after the 2004 constitutional alterations, is the Superior Court of Justice, making it not only more attractive to the interested parties, but also more coherent and similar to other national rules worldwide.

As a result, this paper meant to promote arbitration as suitable form of resolving disputes in Brazil, demonstrating the great advances granted by the enactment of Law No. 9.307/96 in order to preserve the right of parties to seek justice more rapidly, apart from the power given to the State to solve potential conflicts among citizens within its territory, even though not intending to replace it.

\section{REFERENCES}

ARAUJO, Nádia de. A nova lei de arbitragem brasileira e os princípios 
uniformes dos contratos comerciais internacionais elaborados pelo UNIDROIT. In: CASELLA, Paulo Borba (coord.) Arbitragem: a nova lei brasileira (9.307/96) e a praxe internacional. São Paulo: LTr, 1997.

AZEVEDO, Pedro Pontes. A Lex Mercatória e a sua aplicação no ordenamento jurídico brasileiro. Revista Prima Facie. João Pessoa, a. 5, n. 9, pp. 93-105, jul./dez. 2006.

BASTOS, Aurélio W.; CARNEVALE, Marcos. O Poder Judiciário e a Justiça em Números. Revista JC. Rio de Janeiro, n. 173, jan.2015. Available at: <www.editorajc.com.br/2015/01/o-poder-judiciario-ejustica-em-numeros/>. Accessed in $11 \mathrm{dec} .2015$.

BRAGA, Rodrigo Bernardes. Teoria e Prática da Arbitragem. Belo Horizonte: Del Rey, 20098

BRASIL. Lei da Arbitragem - Lei Federal 9.307. Brasília: Senado Federal, 1996.

. Lei de Introdução as Normas do Direito Brasileiro - Decreto 4.657. Brasília: Senado Federal, 1942.

. Novo Código de Processo Civil - Lei Federal 13.105. Brasília: Senado Federal, 2015.

CARMONA, Carlos Alberto. Arbitragem e processo: um comentário à lei 9.307/96. São Paulo: Atlas, 2009.

CONJUR. Mapa do Judiciário: Brasil tem oito juízes para cada cem mil habitantes. Revista Consultor Jurídico. São Paulo, Feb. 12. 2011. Available at: <www.conjur.com.br/2011-fev-12/media-brasil-oitojuizes-cada-cem-mil-habitantes $>$. Accessed in 11 dec. 2015.

COSTA, Sílvio Nazareno. Súmula vinculante e reforma do judiciário. Rio de Janeiro: Ed. Forense, 2002.

DELGADO, José Augusto. A arbitragem no Brasil: evolução histórica e conceitual. Revista Jurídica Consulex. Brasília, v.1, n.11, pp.5-9, nov. 1997.

GAILLARD, Emmanuel, Aspects philosophiques du droit de l'arbitrage international. Leiden: Martinus Nijhoff, 2008.

GONÇALVES, Guilherme. Processos judiciais crescem mais do que a população brasileira. Gazeta do Povo. Pub in Feb. 2, 2009. Available at: <www.gazetadopovo.com.br/vida-publica/ processos-judiciais-crescem-mais-do-que-a-populacao-brasileirablq5wwxvk971w6smnz9m1 gqj2> Accesed in 11 dec. 2015.

GUERRERO, Luis Fernando, Convenção de arbitragem e processo arbitral. São Paulo: Atlas, 2009. 
MAGRO, Maíra; BAETA, Zínia. Guia Valor Econômico de Arbitragem. Rio de Janeiro: Globo, 2004.

MARCO, Carla Fernanda de, Arbitragem internacional no Brasil. São Paulo: RCS, 2005.

MARTINS, Pedro A. Batista. Arbitragem Através dos Tempos. Obstáculos e Preconceitos à sua Implementação no Brasil. In: GARCEZ, e José Maria Rossini. A arbitragem na Era da Globalização. Rio de Janeiro: Forense, 2003.

MERCOSUL. Protocolo de Buenos Aires sobre Arbitragem Comercial Internacional. 1998.

MUNIZ, Tânia Lobo, Arbitragem no Brasil e a lei 9.307/96. Curitiba: Juruá, 2002.

OEA. Convenção Interamericana sobre Direito Aplicável aos Contratos Internacionais. 1994.

PINTO, Luiz Roberto Nogueira, Arbitragem: a alternativa premente para descongestionar o poder judiciário. São Paulo: Arte\&Ciência, 2002.

PONTES DE MIRANDA, Francisco C., Comentários ao Código Civil. Tomo XV. Rio de Janeiro: Forense, 1977.

ROMANO, Cristina Schwansee. The 1996 Brazilian Commercial Arbitration Law. Annual Survey of International \& Comparative Law. San Francisco, v. 5, n.1, pp. 27-47, 1999.

SOARES, Guido F. S. A arbitragem e sua conaturalidade com o comércio internacional. In: PUCCI, Adriana Noemi (coord.) Aspectos atuais da arbitragem. Rio de Janeiro: Forense, 2001

SOARES, Guido Fernando Silva. O Supremo Tribunal Federal e as arbitragens comerciais internacionais: de lege ferenda. Revista dos Tribunais. São Paulo, a.78., v. 642, pp. 38-71, abr. 1989.

STRENGER, Irineu. Contratos Internacionais do Comércio. $3^{\mathrm{a}}$ ed. São Paulo: RT, 1998.

UNICITRAL. Lei Modelo da UNCITRAL sobre Arbitragem Comercial Internacional. 1985.

VAZ, Tatiana. Mais Rápido e mais barato. Revista Exame. Pub. Jul. 6, 2006. Available at: <www.exame.abril.com.br/revista-exame/ edicoes/871/noticias/mais-rapido-e-mais-barato-m0083051>. Accessed in 11 dec. 2015. 